\title{
5 \\ Sorcery Talk, Gender Violence and the Law in Vanuatu
}

\author{
John P. Taylor and Natalie G. Araújo \\ both at La Trobe University
}

In her 1996 paper 'Woman Ikat Raet Long Human Raet O No?' (Do women have the right to human rights or not?), Margaret Jolly reported on a conference on Violence and the Family in Vanuatu held in Port Vila in 1994 and attended by a wide range of women's rights activists, NGO representatives, development practitioners and politicians. ${ }^{1}$ As Jolly described, the conference raised familiar issues that might be expected of similar conferences elsewhere:

What is domestic violence - is it only physical abuse or does it include psychological torture? Does it have to be intended? Who are the perpetrators and who are the victims? How does male violence compare with female violence? Are they sequentially linked? What about violence towards children? What makes violence 'domestic' or private rather than public? Is domestic violence acceptable to some, even legitimate? Is domestic violence increasing? If so, why? ${ }^{2}$

1 Margaret Jolly, 1996, 'Woman Ikat Raet Long Human Raet O No? Women's rights, human rights and domestic violence in Vanuatu', Feminist Review 52: 169-90.

2 Ibid., p. 175. 
As Jolly also noted, however, there was a great deal of discussion around less familiar questions that 'might seem strange to Europeans or Anglo-Australians (though perhaps less so to Aboriginal Australians and many migrants to Australia)'. The first of those questions was, 'Is sorcery violence?' This was followed by further questions, 'Has violence increased as people have moved into towns? Is the growth of the cash economy and the increased isolation of the family to blame? ${ }^{\prime 3}$

As we demonstrate in this chapter, the raising of such concerns regarding the link between sorcery or witchcraft (nakaemas in Vanuatu's lingua franca, Bislama) ${ }^{4}$ and gender violence, including psychological violence, was far from unreasonable, especially when considered from the local perspective. Nor was their framing within a broader context of modernity. Manifesting as a frequent topic of casual conversation and gossip, fear and conjecture surrounding sorcery pervades everyday life in Vanuatu. As several commentators have noted, ${ }^{5}$ concerns regarding the presence of sorcery as a malignant component of everyday sociality are intimately associated with transformations of modernity in the contemporary context. More especially, they are readily associated with new inequalities arising within the context of a rapidly transforming capitalist political economy, with urbanisation, and the breakdown of pre-colonial structures of kinship and authority. Concerns about sorcery are also perpetually regenerated in dynamic entanglement with evertransforming expressions of Christianity, including most recently the emergence of evangelical forms of Pentecostalism.

3 Ibid.

4 Typically blending learned and inherited powers, nakaemas in this generalised sense blurs classic anthropological definitions of 'witchcraft' and 'sorcery', but corresponds to the broadly agreed upon definition of both; i.e., 'the belief, and those practices associated with the belief, that one human being is capable of harming another by magical or supernatural means'. Mary Patterson, 1974, 'Sorcery and witchcraft in Melanesia', Oceania 45(2): 132-60, p. 132. Terry Crowley's definition in A New Bislama Dictionary therefore reads as follows: 'nakaemas (n) sorcery, witchcraft, evil force directed by humans that can be used to harm and kill people'. Terry Crowley, 1995, A New Bislama Dictionary, Suva, Fiji: Institute of Pacific Studies, p. 155.

5 Knut Rio, 2010, 'Handling sorcery in a state system of law: Magic, violence and kastom in Vanuatu', Oceania 80(2): 182-97; Jean Mitchell, 2011, “'Operation restore public hope”: Youth and the magic of modernity in Vanuatu', Oceania 81(1): 36-50; Miranda Forsyth, 2006, 'Sorcery and the criminal law in Vanuatu', Lawasia Journal 1: 1-27; John P. Taylor, 2016, 'Two baskets worn at once: Christianity, sorcery and sacred power in Vanuatu', in Christianity, Conflict, and Renewal in Australia and the Pacific, ed. Fiona Magowan and Carolyn Schwarz, pp. 139-60, Leiden: Brill Publishers (under contract); Taylor, 2015, 'Sorcery and the moral economy of agency: An ethnographic approach', in Gender and Person in Oceania, ed. Anna-Karina Hermkens, Rachel Morgain and John P. Taylor, special issue of Oceania 85 (1): 38-50. 


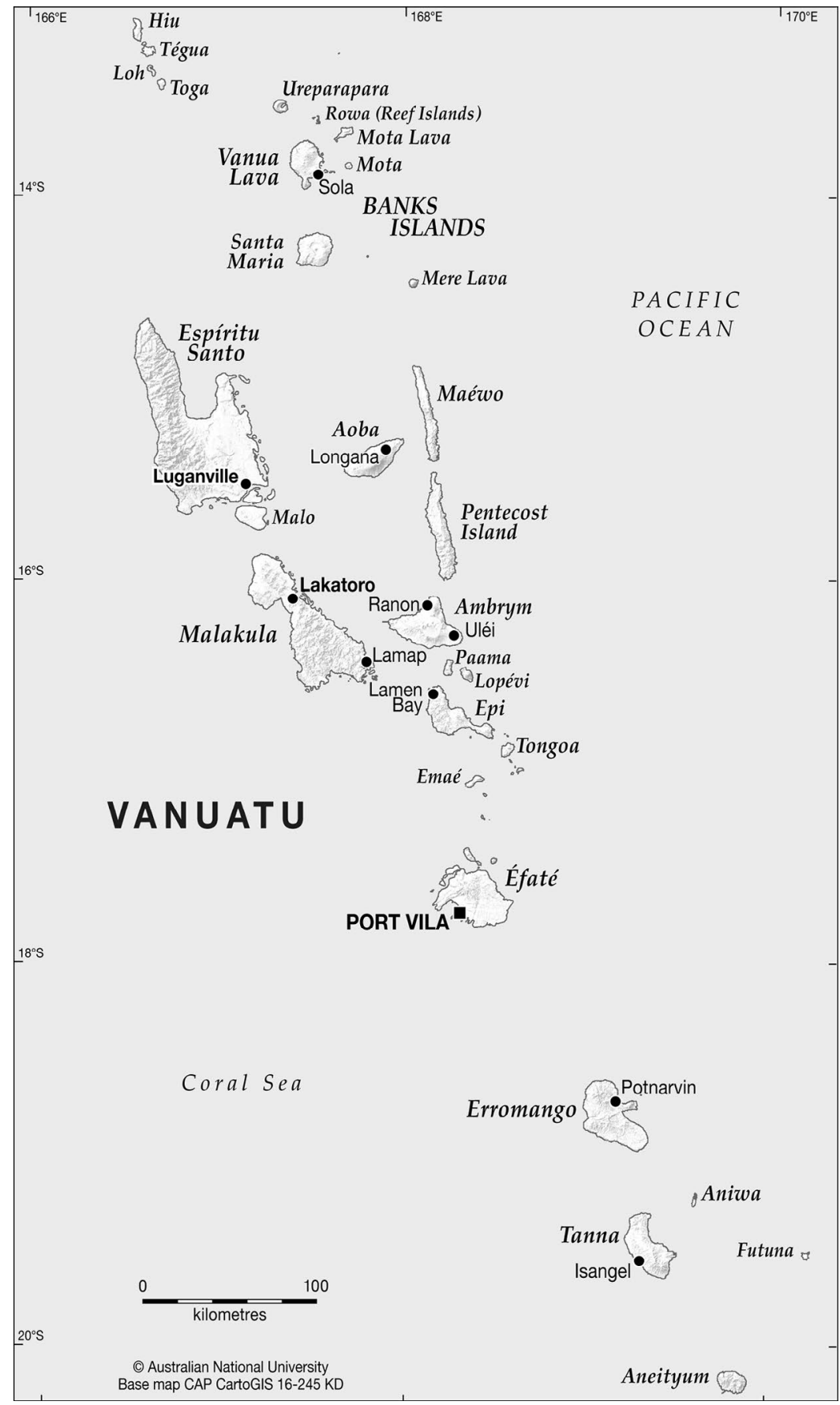

Map 4. Vanuatu

Source. (C) The Australian National University. Base Map. CAP CartoGIS ANU 16-245 KD 
Within this context, and as this chapter demonstrates, sorcery narratives circulate as ambiguous expressions of power and gendered agency. Focusing primarily on several specific sorcery-related narratives recorded by John P. Taylor while conducting fieldwork in Vanuatu's 'second town', Luganville, in 2006-2007, ${ }^{6}$ we demonstrate how talk about sorcery articulates and reinscribes relations of power in two key ways. First, we consider narratives concerning the transformation of social context and uses of nakaemas during colonialism. Highlighting as they do the positive value of sorcery as a legitimate mechanism of chiefly authority and juridical power in the past, these oralhistorical analyses speak to a lamented breakdown of kastom (loosely, indigenous knowledge and practice). More especially they express the perceived demise of central hierarchies of masculine power associated with the 'graded society', a hierarchical system of leadership based on competitive exchange and porcine sacrifice, such that occurred within the context of colonialism and is perpetuated in the form of the nation state. ${ }^{7}$ Within the context of this historical rupture, sorcery is understood to have become dangerously unbound from 'traditional' structures of male authority. Through the introduction of a Christian morality of 'good' and 'evil', rather than appearing as a useful mechanism of social control, it now became cast as a malignant force of modern chaos. Far from simply articulating a loss of male agency in the face of colonial and state power, however, sorcery in this transformed context is understood to have proliferated into new forms that may be used to challenge the powers of colonialism and the state. Second, while such narratives can thus be read positively as expressions of indigenous agency, we are also attentive to the crucial gendering of sorcery beliefs and their associated narrative tropes in Vanuatu. This is not to say that women are not believed to use sorcery in Vanuatu. Indeed, while men appear to be the main practitioners of sorcery, this is not exclusively the case. ${ }^{8}$ More especially, focusing on sex-related accounts of sorcery activity, including what we tentatively refer to as 'sexual assault sorcery', we argue that much sorcery-related discourse reifies gender-based inequalities. Such discourse is often

6 John P. Taylor, 2010, 'Janus and the siren's call: Kava and the articulation of gender and modernity in Vanuatu', Journal of the Royal Anthropological Institute 16(2): 279-96; Taylor, 'Two baskets worn at once'; Taylor, 'Sorcery and the moral economy of agency'.

7 See also Knut Rio, 2002, 'The sorcerer as an absented third person: Formations of fear and anger in Vanuatu', Social Analysis 46(3): 129-54.

8 For example, Forsyth, 'Sorcery and the criminal law in Vanuatu'. 
aimed at curtailing female agency by normalising the use of violence against women, including sexual violence, as a form of punitive social justice.

\section{Background}

With approximately 110 languages spoken across a current population of around 250,000 people, Vanuatu is an archipelago of stunning linguistic and cultural diversity. Since gaining independence in 1980 from joint British and French colonial rule, it has also become a place of increasing economic inequalities. Like the majority of the Pacific's so-called least developed countries, being relatively isolated in geographical terms, Vanuatu has struggled to build up a strong commodity economy and instead relies heavily on foreign aid. At the same time, within Vanuatu there is often a marked contrast between rural and urban livelihoods. Rural settlements typically consist of dispersed hamlets of around 50 to 300 people. While subsistence agriculture is the primary economic activity in rural areas, this is supplemented by cash incomes typically derived from copra, timber, cocoa and increasingly kava production. By contrast, for those living in one of the two main urban centres, Port Vila and Luganville, dependence on the cash economy is more especially marked. Without easy access to land for gardens or dwellings, and in a context in which conspicuous consumption is of increasing cultural importance, for most urbanites participation in wage labour and entrepreneurship is vital. With jobs remaining relatively scarce, and with an increasingly educated and youthful population, this is a highly competitive sphere of engagement. At the same time, with an increasing dependence on imported foods - especially rice, instant noodles and tinned fish - ni-Vanuatu in urban contexts especially are facing new health challenges such as obesity and diabetes. ${ }^{9}$

Sorcery beliefs, discourses and sorcery-related actions are ubiquitous throughout Vanuatu but assume a particular character and intensity in town. Indeed, as the present discussions from Luganville indicate, within the urban context sorcery is often tied to economic and marital or romantic jealousies. By contrast, sorcery accusations in rural contexts

9 Kelsey Needham Dancause et al., 2013, 'Behavioral risk factors for obesity during health transition in Vanuatu, South Pacific', Obesity 21(1): E98-E104. 
are more often tied to land disputes. In all contexts, however, they are not only closely tied to violence, including gender violence, but also to health-seeking strategies and issues of law and governance. Sorcery accusations are a key factor in much gender-based and other forms of violence. ${ }^{10}$ Sorcery impacts negatively on local responses to illness, that incorporate traditional, Christian and biomedical healthcare systems. The question of how to practically confront sorcery through legal or other mechanisms is a continually fraught concern, ${ }^{11}$ as demonstrated in a recent conference on Sorcery and Witchcraft-Related Killings in Melanesia at The Australian National University in Canberra. ${ }^{12}$

Sorcery beliefs and practices are not uniform across Vanuatu. Indeed, contemporary sorcery-related anxieties are linked to human mobility and the 'mixing' of different island-based or languagebased populations, including their diverse forms and knowledge of sorcery. For this reason, urban settlements, places of employment, and public spaces such as hospitals, kava bars and cargo ships used for inter-island transport represent particularly dangerous sites of sorcery-related activity. At the same time, stereotypes exist across class and ethnicity, with sorcery practice being attributed especially to particular islands (such as Ambrym, Malakula and Maewo) and also to poorer, 'grassroots' groups. ${ }^{13}$ There are also discernible differences in the gendered experience of sorcery, that accord with more generalised patterns of gender inequality and gender violence. ${ }^{14}$ For example, while both men and women may be subject to attacks on wealth and property, women may also fall victim to sex-related sorcery attacks. Speaking more generally, the literature on Vanuatu suggests a strong link between sorcery and masculine power, with men maintaining their place in political hierarchies by strategically comingling benevolent leadership with the ever-present threat of a dangerous capacity to harm, including the use of spiritual power

10 Rio, 'Handling sorcery in a state system of law'; Taylor, 'Sorcery and the moral economy of agency'.

11 Forsyth, 'Sorcery and the criminal law in Vanuatu'.

12 Conference on Sorcery and Witchcraft-Related Killings in Melanesia, 5-7 June 2013,

The Australian National University, Canberra.

13 Mitchell, "“Operation restore public hope"”.

14 Chakriya Bowman, Jozefina Cotura, Amanda Ellis and Clare Manuel, 2009, Women in Vanuatu: Analyzing Challenges to Economic Participation, Washington DC: The World Bank. 
wielded either by themselves or their followers. ${ }^{15}$ At the same time, male religious leaders and chiefs often campaign against sorcery, thereby demonstrating their moral capacities, while protecting themselves from the threat of sorcery accusation. ${ }^{16}$ Such moral campaigns serve to reinforce both fears of sorcery and fears of being accused. The threat of such masculine power is especially apparent among the growing numbers of new Pentecostal churches, but is also palpable among Anglicans and other established churches. ${ }^{17}$

In this chapter, we contribute to the growing discussion of sorcery and sorcery-related beliefs and practices in Vanuatu, and in the broader region, particularly as these intersect with questions regarding gender violence, the law and human rights concerns more generally. As acknowledged in a UNIFEM report $(2010),{ }^{18}$ sorcery is clearly linked to violence, including gender violence, and sorcery-related violence appears to be increasing in Vanuatu and across Melanesia. ${ }^{19}$ Indeed, results of a large-scale statistical survey $(2,326$ respondents) into the status of women in Vanuatu found that of all forms of violence, 'violence due to sorcery' was of the greatest

15 William L. Rodman, 1973, 'Men of influence, men of rank: Leadership and the graded society on Aoba, New Hebrides', PhD thesis, University of Chicago; Jolly, 'Woman Ikat Raet Long Human Raet O No?'; Tim Curtis, 1999, ‘Tom's Tambu house: Spacing, status and sacredness in South Malakula, Vanuatu', Oceania 70(1): 56-71; Rio, 'Handling sorcery in a state system of law'; John P. Taylor, 2010, 'The troubled histories of a stranger god: Religious crossing, sacred power, and Anglican colonialism in Vanuatu', Comparative Studies in Society and History 52(2): 418-46.

16 On the 'moral economy of agency' that surrounds sorcery and expressions of personhood, see Taylor, 'Sorcery and the moral economy of agency'.

17 Taylor, 'Two baskets worn at once'.

18 UNIFEM, 2010, 'Ending violence against women and girls: Evidence, data and knowledge in the Pacific Island Countries. Literature review and annotated bibliography', Suva: UNIFEM Pacific Sub-Regional Office.

19 See, for example, Richard Eves, 2000, 'Sorcery's the curse: Modernity, envy and the flow of sociality in a Melanesian society', Journal of the Royal Anthropological Institute 6(3): 453-68; Rio, 'Handling sorcery in a state system of law'; Philip Gibbs, 2012, 'Engendered violence and witchkilling in Simbu', in Engendering Violence in Papua New Guinea, ed. Margaret Jolly, Christine Stewart with Carolyn Brewer, pp. 107-35. Canberra: ANU E Press. 
overall concern for women (at 49 per cent). ${ }^{20}$ In 2007 the international press reported on a high-profile case that resulted in rioting in Port Vila. ${ }^{21}$ This incident was not only suggestive of the links between sorcery and gender violence, as well as inter-ethnic violence, but also of the role that Christian and kastom-based institutions play in encouraging sorcery beliefs, as manifestations of 'dark powers'. The violence was sparked by allegations that sorcery was used to kill a woman following a marital dispute, with people from the victim's home island (Tanna) attacking the accused husband's island community (Ambrym). Police were unable to control the situation and three people were killed. The Malvatumauri National Council of Chiefs finally settled the dispute and called on members of the Melanesian Brotherhood, a male sect of the Anglican Church, ${ }^{22}$ to remove the malignant spiritual powers at work. ${ }^{23}$

While Papua New Guinea has repealed its Sorcery Act, sorcery practice is criminalised in Vanuatu according to state law, and in 2012 the first sorcery conviction occurred under section 151 of the Penal Code. Debate about the effectiveness of such legislation in Vanuatu nevertheless persists, with questions being raised as to whether the existence of sorcery legislation entrenches sorcery belief through legitimating it, and whether the introduction of laws against sorcery accusations might help reduce sorcery-related violence or merely drive it underground.$^{24}$ However, while sorcery cases do very occasionally go to trial in Vanuatu, ${ }^{25}$ they are typically handled by chiefs through state-sanctioned mechanisms of kastom law. More often still they are

\footnotetext{
20 Vanuatu Women's Centre/Vanuatu National Statistics Office, 2011, Vanuatu National Survey on Women's Lives and Family Relationships, Port Vila: Vanuatu Women's Centre, p. 54. While certainly praiseworthy for reporting this important statistic, broader questions concerning the nature of these concerns were not discussed elsewhere in the 246-page document. This includes such crucial issues as whether women are concerned about sorcery itself as a form of violence, or about physical violence resulting from sorcery accusations. While certainly praiseworthy for taking steps towards acknowledging sorcery's negative impact on human security by including questions regarding sorcery in the research question, the failure of any attempt to understand the significance of these findings points to a general incapacity within development industry approaches and analytic perspectives concerning sorcery.

21 Emma O'Brian, 2007, 'Vanuatu chiefs ban black magic after riot over woman's death', Bloomberg, 27 March.

22 Taylor, 'The troubled histories of a stranger god'.

23 Rio, 'Handling sorcery in a state system of law.

24 Forsyth, 'Sorcery and the criminal law in Vanuatu'; and cf. Nicholas Herriman, 2006, 'Fear and uncertainty: Local perceptions of the sorcerer and the state in an Indonesian witch-hunt', Asian Journal of Social Sciences 34(3): 360-87.

25 Forsyth, 'Sorcery and the criminal law in Vanuatu', pp. 21-22.
} 
handled through mechanisms based in Christian churches including processes of dispute resolution, counselling and the exorcism of suspected sorcerers. As the following examples demonstrate, sorcery is related to governance mechanisms in other ways: for example, in pervasive beliefs that nakaemas can be used to influence legal outcomes, the strength of sorcery is often considered greater than that of the law. For this reason, anyone involved in court trials, including chiefs, lawyers and judges, presents a potential target for sorcery attack by those wishing to affect legal outcomes. Disturbingly, several anthropologists have suggested that Police Force personnel are often believed to 'act like sorcerers' ${ }^{26}$ Indeed, like many Christian spiritual leaders, such as the members of the Anglican Melanesian Brotherhood, who are said to work on the 'frontline' against such 'dark powers', ${ }^{27}$ police officers occupy a dangerously ambiguous position with regard to malignant sacred powers.

Although most individuals in Vanuatu are able to describe personal encounters with sorcery, most sorcery-related activity does not take the form of sorcery per se, nor indeed of sorcery-related violence. Rather, and along with the everyday embodied fears of sorcery that individuals carry throughout their daily lives, sorcery primarily appears discursively, in the constant flow of talk, comingled in everyday intrigue, gossip and conjecture. For this reason, the focus in this chapter is to present a preliminary analysis of the ways in which such sorcery talk is imbricated with changing relations of power, first in relation to modernity as rupture consequent on the experience of colonialism, and second in relation to novel inequalities in gender relations. ${ }^{28}$

As Hannah Arendt noted, the stories we tell ourselves, about ourselves and others, form an essential component of identity-making and of the constitution and transformation of private and public life. ${ }^{29}$ As such, the sorcery-related narratives explored here represent complex, socially and historically embedded expressions of relational agency. Here we focus on an analysis of sorcery narratives as complex articulations of agency occurring within the context of political

\footnotetext{
26 Rio, 'Handling sorcery in a state system of law', p. 134.

27 See Taylor, 'Two baskets worn at once'.

28 Also John P. Taylor, 2008, 'The social life of rights: Gender antagonism, modernity and raet in Vanuatu', The Australian Journal of Anthropology 19(2): 165-78.

29 Hannah Arendt, 1998 [1958], The Human Condition, Chicago: University of Chicago Press.
} 
and gender-based inequalities. Our analysis concentrates attention on three specific historically constituted and gendered sorcery narratives. In the first, two well-respected older men lament the demise of sorcery as a legitimate expression of masculine authority. In this pre-colonial context, sorcery is understood to operate as a realm of esoteric power that works to uphold social order, including hierarchical relations between different kinds of men within society. By contrast, in the second a young man recounts his own experience of having utilised sorcery to aid in the carrying out of a gang rape. In this case sorcery is understood to have fallen into the hands of young, relatively disempowered men. Rather than appearing as an integrated mechanism of chiefly legal authority, as in the previous example, here sorcery is used to express a form of masculine agency that is subversive, anti-authoritarian and counter-hegemonic, both of chiefly justice and state law. All the while, however, in the present context such narratives work to uphold what R.W. Connell has called the 'patriarchal dividend', ${ }^{30}$ an assumed set of rights and privileges that structure unequal power relations between men and women. Finally, and in conclusion, we apply these insights to a high-profile legal case concerning sorcery and gender-based violence, as described by Miranda Forsyth. ${ }^{31}$

\section{Masculine authority and the unbinding of sorcery from chiefly power}

For our first example we present at length an extract from an interview conducted with two well-educated and respected men, both in their 50 s that took place in Luganville. The two men, referred to simply as Michael and Paul for reasons of anonymity, hail from Ambrym and Malakula respectively, the former being a place with a reputation for producing particularly strong sorcery and sorcerers.

30 R.W. Connell, 1995, Masculinities, Berkeley: University of California Press.

31 Forsyth, 'Sorcery and the criminal law in Vanuatu'. 
Michael: On Ambrym we have two societies: one that we call the 'common society' and the other the 'seclusion society'. This thing, nakaemas, or black magic, it resided in the seclusion society and was controlled by them [high-ranking men, or today, 'chiefs'] from above. ${ }^{32}$

Paul: Black Mafia!

Michael: And in the kastom ranking system, if you take a rank without following the proper road, there will be questions and you must straighten it [i.e., correct it]. But if you don't straighten it, they [chiefs] use this thing [nakaemas] to return things to how they were before. At the same time, they use it [nakaemas] to keep peace, law and order inside society. A man who disobeys? He won't be able to escape it. Everyone must obey.

JT: So this kind of magic, is it like a form of security for the community?

Paul: Yes, they [chiefs] used it to provide security, to make sure that there is order at all times. However, it is always the last resort. If someone does something that they're not supposed to do, maybe first they'll warn him. The second time, their family will act. And the third time - usually when someone does something wrong the parents or chief will try to solve the problem - but if things continue and it reaches a stage where he no longer obeys, the chief, we say, 'he tells' [hemi telem: to notify, or secretly inform, see discussion below].

Paul: Black Mafia!

Michael: Now the talk is out. If you do something wrong, you're told to fix it, for instance by paying a fine. All the leaders or chiefs will come and say, 'You, my child, it's best that you see and understand [luk save] that you've done something wrong, and that you fix it and make it straight. Then you can go back, play and live well.' But if you go and do it again, and go out of control, they'll say the following words: 'I see this child is too willful and disobedient [stronghed tumas].' That's it - finished now. They'll say those words, and then there will be people around him who will just affect them [makem hem, that is, to harm, or otherwise affect someone by supernatural means]. But it would be wrong to blow this up and say that when this occurs, this is an issue for every man. If you're a good man, it's not your issue-it's not your concern.

32 In a follow-up interview, Michael further explained the punitive workings of nakaemas by using English legal terminology, stating that it works 'like a penalty system' made up of 'judgments' within a 'justice system'. Interview conducted by John P. Taylor, Luganville, 2007. 
JT: So you can walk around freely, and you'll be alright?

Paul: That's correct. It's not your concern-they don't poison indiscriminately.

JT: So where did this go wrong? How did this go wrong?

Michael: Cash! Because society in the past was small and its power was enough to keep the peace in that small place. But that small population grew, and more culture came in, and it destroyed that fragile system. And when it was destroyed, people had no other option but to resort to these things [that is, using nakaemas inappropriately].

The interview material presented here shows that, in contemporary understandings, sorcery in the past was valued as a largely positive mechanism of masculine chiefly hierarchy and social control, and seen as an integral component of kastom law. By contrast, according to local narratives of cultural and masculine loss associated with the breakdown of kastom structures of governance during the colonial period, sorcery today represents a largely negatively valued agency. Unbound from previously integrated chiefly structures, and as demonstrated further below, sorcery today is understood to operate in a dangerously liminal space that lies beyond the reach of both state and kastom law. These narratives suggest that sorcerers are beyond legal prosecution not only due to ontological incompatibilities concerning evidence, but more so because their powers are seen as so much greater than those of the law.

As well as asserting the legitimacy of indigenous forms of knowledge and power displaced through colonialism, such conversations reflect Robert Tonkinson's claim that, prior to colonialism, 'sorcery was considered a legitimate institution', one that 'kept people in line'. ${ }^{33}$ As he suggests further, throughout the ensuing colonial period, and as a part of the demise of male chiefly power and legitimacy through processes of missionisation and 'pacification', there occurred a profound 'democratisation of sorcery'. As Knut Rio describes:

33 Robert Tonkinson, 1981, 'Sorcery and social change in Southeast Ambrym, Vanuatu', Social Analysis 8: 77-88, p. 79 . 
The practice became available to all people through inter-island exchange. In the highly mobile era of colonialism, people brought back sorcery from plantations on other islands and from the urban cultural conglomerate. Sorcery became the tool of everyone and everybody. Those who had purchased sorcery could now pose a threat to others without being legitimately known as vanten hanglam (high men). ${ }^{34}$

In the above transcript, Michael in particular asserts that sorcery in the past did not constitute an offence to be controlled and legislated against, as it is in the present. By contrast, while certainly dangerous, it is considered by him to have constituted a positively valued legal mechanism in and of itself, one that was used by high-ranking chiefs to bring about justice, law and order. ${ }^{35}$ Law and sorcery are in this way understood to have been entwined socially and institutionally within what are typically referred to in the anthropological literature as 'secret societies' - a ritualised system of male initiation cults ${ }^{36}$ and the related 'graded society' - a more public sphere of competitive exchange and porcine sacrifice through which ni-Vanuatu men and women rose in status by moving through a hierarchy of named grades. ${ }^{37}$ Indeed, linked in this way to social hierarchy, leadership and juridical control, sorcery appears as a defining feature in the distinction between what Michael instructively describes as the 'common society' and a masculine, chiefly and spiritually powerful 'seclusion society'. Speaking more generally, sorcery is understood to have been incorporated as a part of a normative juridical framework, having been used to support a sanctions-based model of social order and moral duty presided over by high-ranking men.

\footnotetext{
34 Rio, 'The sorcerer as an absented third person', p. 132.

35 The allusion here, including in the metaphoric association of height with masculine power, is to the so-called 'secret men's cults' that occur across Northern Vanuatu. See Michael R. Allen, 1967, Male Cults and Secret Initiations in Melanesia, Melbourne: Melbourne University Press. More specifically in Ambrym where they are also linked to esoteric powers including sorcery, see Rio, 'The sorcerer as an absented third person'.

36 See especially Allen, Male Cults and Secret Initiations in Melanesia.

37 Rodman, 'Men of influence, men of rank'; Michael Allen (ed.), 1981, Vanuatu: Politics, Economics, and Ritual in Island Melanesia, Sydney: Academic Press; Peter Blackwood, 1981, 'Rank, exchange and leadership in four Vanuatu societies', in Vanuatu: Politics, Economics and Ritual in Island Melanesia, ed. Michael R. Allen, pp. 35-84, Sydney: Academic Press; Margaret Jolly, 1994, 'Hierarchy and encompassment: Rank, gender and place in Vanuatu and Fiji', History and Anthropology 7(1-4): 133-67; on this point also see Rio, 2010, 'Handling sorcery in a state system of law', pp. 137-38.
} 
The decoupling of sorcery from exclusive chiefly juridical control clearly corresponds to a narrative concerning the breakdown of the graded hierarchies of male chiefly power during colonialism. Indeed, this breakdown is understood to have been made possible by the unbinding of nakaemas as a legitimate form of social control, and more especially as a mechanism of indigenous law, from the social and political structure. The criminalisation of sorcery in state law during the colonial period and at independence can be seen to have contributed to the breakdown of male chiefly authority and power within the 'seclusion society'. Ironically, colonialism can in this way be seen to have unwittingly propelled rather than reduced sorcery beliefs, especially by allowing for the dispersal of sorcery powers across society at large. Indeed, according to this narrative, previously restricted as an extension of the authority of high ranking men, the power of nakaemas was now dangerously set loose, potentially extending everywhere as a largely uncontrolled and widely dispersed sphere of concealed agency.

As the following discussion indicates, however, while forming what might be considered an expression of anticolonial agency, particularly through challenging introduced codes of legality and juridical authority, in this so-called 'democratisation', the power of sorcery was and is still largely controlled by men, and indeed became used in acts of violence against women. At the same time, sorcery remains linked to power and authority, and for this reason an ambivalent link exists in contemporary Vanuatu between sorcery and Christianity, sorcery and the law, and sorcery and masculine power more generally. This comes as no surprise when we consider the oral-historical link that is often made between sorcery and pre-colonial systems of male authority and justice. On this point it is particularly interesting to note the significance of Paul's description of the so-called 'seclusion society' as a 'Black Mafia!' This richly suggestive cross-cultural metaphor, drawn from popular culture and commonly used to describe Ambrym sorcerers in particular, aptly calls to mind the present association of sorcery with a pre-Christian time of 'heathen darkness', while at the same time describing the secretive sphere of masculine power by which sorcery operates, both in the past and in the present. Indeed, the obscure chiefly acts of 'telling' and 'making' described here reflect broader understandings concerning the authoritative and disciplinary power of chiefly talk, found for example in Lamont Lindstrom's 
Foucauldian analysis of the John Frum movement on Tanna. ${ }^{38}$ In colonial and contemporary times the potentially dangerous power of oblique or indirect speech is also harnessed by Christian priests, including missionaries, in powers of cursing, for instance. ${ }^{39}$ Today obscure magical speech is understood to be more widely distributed among men, especially in a form of nakaemas known as swit maot (sweet mouth), a beguiling talk that is especially used by young men to seduce women and by politicians to win votes.

\section{Sorcery and gender violence}

One of the strongest narratives associated with modernity in Vanuatu is that kastom has remained more robustly intact in rural contexts than in urban ones, which are typically seen to have been more thoroughly exposed to the ravages of externally derived technologies and socioeconomic forces of change through the colonial period and after. Relating to this is an understanding that indigenous leadership systems, including present manifestations of kastom law, are more strongly represented in island villages than in town. Correspondingly, the idea of sorcery as a force unbounded from social structures and institutions, including the law, is often seen to be more closely associated with urban life. ${ }^{40}$ With modernity, and especially in towns where people live in communities that are dangerously 'mixed' in terms of island or place-based identity, use of nakaemas is believed to have proliferated into multiple forms. Far from comprising mechanisms of chiefly law, these contemporary forms of nakaemas are associated with antisocial and criminal behaviour. Terms in Bislama describing these forms include nakaemas, which is used as a generalised term for what generally accords to sorcery/witchcraft in anthropological vocabulary. More specifically it describes the ability to change one's form into a spirit animal, such as a shark or a hawk, and to evade

\footnotetext{
38 Lamont Lindstrom, 1990, Knowledge and Power in a South Pacific Society, Washington, DC: Smithsonian Institution Press.

39 See, for example, Taylor, 'The troubled histories of a stranger god', p. 59; Taylor, 'Two baskets worn at once'; Knut Rio and Annelin Eriksen, 2013, 'Missionaries, healing and sorcery in Melanesia: A Scottish evangelist in Ambrym Island, Vanuatu', History and Anthropology 24(3): 398-418.

40 For a counter-example, see Annelin Eriksen, 2012, Gender, Christianity and Change in Vanuatu: An Analysis of Social Movements in North Ambrym, Aldershot and Burlington VT: Ashgate Publishing, p. 60.
} 
the law or commit law-breaking acts such as theft. Other magical forms in Bislama include bibi, also known as kilim tinting (to kill thought), which describes mental suggestion and memory erasure; posen (poison) and sometimes masin (from medicine), which describe magically assisted acts of poisoning; swit maot (sweet mouth), a form of beguiling talk (see above); and su, the ability to move invisibly and imperceptibly through physical space, or as one Pastor described it to Taylor, the ability to 'walk around in the spirit of another power' (spirit blong narafala power).

As the following discussion indicates, however, sorcery remains an important component of male chiefly power, including as an expression of what Siobhan McDonnell has described for Efate as 'Masters of Modernity' in land disputes and business enterprise. ${ }^{41}$ Yet in the post-independence period it is young men who are understood to have benefited most from sorcery's so-called 'democratisation'. In particular, according to local narratives, young men in town have appropriated and creatively transformed nakaemas for two main purposes: stealing money and engaging in illicit sexual activity. Su is in this way especially associated with the activities of wayward young men and in gender-related forms of violence. As the Pastor quoted above described it further:

At this time, now, nakaemas is like - many young men play with these rubbish things. It's like, sometimes they think it's a good thing, and they take hold of it, and they're glad. But then they hurt someone else. For instance, to get girls, or to go inside of the house of another man to spoil their wife. To walk around like this, with $s u$.

In a very graphic account of what might be called 'sexual assault sorcery', one male interlocutor in his early twenties, also from Ambrym and whom we here call David (also a pseudonym), openly claimed to be a practitioner of nakaemas. In the following transcript, David describes how he and a group of male companions once employed such magic to engage in sexual assault as disciplinary social justice on a young woman. Narratives relating to such punitive acts, particularly directed at transgressions of gendered norms and expectations relating to patriarchy, are relatively common. Whether

41 Siobhan McDonnell, 2015, “The land will eat you": Land and sorcery in North Efate, Vanuatu', in Talking it Through: Responses to Sorcery and Witchcraft Beliefs and Practices in Melanesia, Miranda Forsyth and Richard Eves, pp. 137-60. Canberra: ANU Press. 
or not the narrated events are to be considered 'real' in any material sense, such stories circulate widely in Vanuatu as expressions of masculine agency-including especially, albeit not exclusively, the agency of male youths - and can be seen as part of more generalised processes involving the oppression and surveillance of women, as well as violence against women generally. As such, they reflect other, non-sorcery-related scenarios, whereby women are punished for transgressing gender-based norms and expectations, in acts of shaming, physical violence, and surveillance, or in other means of enforcing male hegemony. This can be seen in recent analyses of chiefly and other social injunctions placed on female behaviour, including especially in prohibitions against the drinking of kava or in personal adornment, ${ }^{42}$ such as chiefly bans on the wearing of 'trousers' ${ }^{43}$ It can also be seen in male reactions to women's rights movements, whereby women's empowerment is interpreted relationally as an infringement of male 'rights'. ${ }^{44}$ Furthermore, this example shows how sorcery today represents expressions of agency that operate specifically outside or beyond the reach of the law, both Western and kastom. Not only are lawbreaking sorcerers unable to be prosecuted due to reasons of evidence and causality, but also, as this account suggests, their strength is often considered greater than the strength of the laws of the state. The following conversation began with a description that mirrors closely those of Michael and Paul (above) with regard to the view of sorcery as intimately tied to chiefly law in the past. This similarly included how chiefly power and authority is directed through chiefly injunctions and enacted as a function of hierarchical relations between men in a concealed manner.

David: On Ambrym, people use it [nakaemas] for punishment. Now they use Police. Before, they didn't use Police. It's like Chief Willy Bongmatur told me one time: before, there were no Police. You make trouble the first time, you go the nakamal [men's house] for a meeting, and when it's finished, they give you a chance. Okay, next time at the meeting, when they see that you've done the same thing time

\footnotetext{
42 Taylor, 'Janus and the siren's call'.

43 Benedicta Rousseau, 2004, 'The achievement of simultaneity: Kastom in contemporary Vanuatu', PhD thesis, Cambridge University; Maggie Cummings, 2008, 'The trouble with trousers: Gossip, kastom, and sexual culture in Vanuatu', in Making Sense of AIDS: Culture, Sexuality, and Power in Melanesia, ed. Leslie Butt and Richard Eves, pp. 133-49, Honolulu: University of Hawai'i Press.

44 Taylor, 'The social life of rights'.
} 
and again, they proclaim now that it would be best if you go out of society' [yu aot long sosaeti]. When they say this - 'it would be best if you go out of society' - this is a form of talk by which they mean, 'it would be best if you were simply dead'.

JT: And when that happens, someone will makem you [harm/affect by supernatural means]?

David: Yes, there are men for this present already. You and I will not know who kills him, but the poison will happen. You'd think there must be a witness - an eyewitness. But if I come to kill you, you won't see me.

Speaking hurriedly, David abruptly changed the direction of the conversation to explain how sorcery represents a secretive sphere of masculine competition that operates beyond the grasp of the common or Western-style law. Importantly, and underlining the argument that sorcery narratives represent counter-hegemonic expressions of agency, according to David's reckoning, the reason why it is so difficult to bring sorcery cases or carry out sorcery convictions within the context of Western law is not due to ontological incompatibility, especially concerning theories of causality. Rather, this incapacity of Western law to apprehend contemporary sorcerers is due to the unbound capacity of sorcery and to its ability to overpower the force of the law:

David: There's never been a court case for posen [poison, or poisoning through sorcery], or someone winning a court case against someone using posen against them. Never! If you talk against someone who uses posen, you must either shoot him dead, or whatever [i.e., physically murder them], but you will never be able to beat them in court. As we see it, we might know that 'this man has done it', but to tell it out publicly? You can't win. Because once you tell it out publicly, saying, 'this man has done it', you must know [i.e., possess the esoteric knowledge of] much more protection than that man. If he tries to use whatever [form of nakaemas], you must know you have many ways to protect yourself from him. Because if you want to talk against him, saying 'you hold something' [for the purposes of nakaemas], but you don't have anything to protect yourself, you won't say anything. Because when you say anything in public, he will start to makem you, and he'll never stop. 
In narratives such as these, sorcery-related acts are described as acts of concealed agency that exist in a competitive sphere that lies both beyond the grasp of the law and the visible 'openness' of public space. In Vanuatu, according to our preliminary analysis at least, such exchanges are typically understood to take place between men, or groups of men. Over the course of such exchanges, acts of sorcery and accusations of sorcery are entangled with acts of physical violence, with the only ultimate equivalent of the power of sorcery being murder.

Changing the direction of conversation again, David went on to describe a personal example in which young men employed nakaemas to engage in non-consensual and therefore illegal sexual activity with an unsuspecting young woman. In this instance such sorcery was used to facilitate what was described as a brutal gang rape, one that was enacted as a punitive expression of masculine power. In the narrative David began by observing that 'in town, young men use nakaemas especially for women'. He then went on to describe an occurrence in which one of his classificatory brothers, a young man like himself, had been slighted and offended by a girl who had spurned his advances. After returning home to tell of the incident, one of the two young men's classificatory fathers (also in his twenties, and for whom he used the term 'Daddy') suggested that they teach her a lesson, especially as the woman had allegedly spoken badly of their Ambrymese island identity in brushing off the advances of David's brother.

David: So, do you know what happened? We jumped on a truck. We went down into town and brought markers - writing markers. We went to the house of the girl. It was still early. But, regarding the nakaemas where you go inside of houses for women, there are two. One - this brother who the woman swore at carried the first. He hid close to the house. Okay, this Daddy carried the second one. With the second one, you can't hurry. You must walk around slowly. If you hurry - once you get in the house, you and I and everyone in the house will die. You must walk around slowly with it, because it makes everyone in the house sleep. Because its power makes everyone sleep.

So, when this second one started working, we could hear everyone inside saying 'goodnight', 'goodnight', and the light switched off. They went to sleep. Then, quickly, the other one who held the first one, he held the one for opening doors. He opened the door. We went 
inside - these two things, they're called 'su'. So, su, when you use them, you can't place it close to a person's heart. If you put it on someone's heart, they'll die.

JT: What is it? A leaf? Stone?

David: It's something that the old men make, and you can pay them for it.

JT: Can it be anything?

David: No, it's something special. Some are similar to a flying fox. Sometimes when you've finished using them they fly and then hang all about, especially in banyan trees. Have you seen? I've seen! Because mostly they're so powerful you can't see them. But some are just stones. The first one we used [for opening the door] was a stone, but the second one that he took to use - if you want to carry one on a ship, you have to bury it in a tin, buried in some dirt, and then you can ship it. Because if you carry it on the ship uncovered, the ship will sink. Its power is strong.

So, we went inside, carried out this girl-everyone inside slept, and knew nothing. We carried her and lay her outside. Okay, all the boys did their work on her now - took off all her clothes. One had sex with her, then finished - then another one-another one. Once all of us had finished, we used the markers. Wrote names on whatever part of the body you wanted to - we just wrote it. She slept, and didn't know anything. But in the morning? They found out she'd slept outsideand she was greatly ashamed for having slept outside.

JT: And all the writing?

David: Yes, with all the writing. She read this writing, and she could tell that the sounds of the writing were the sounds of Ambrym. So, she understood that 'No, I said something no good to them all'.

Okay, time passed, and one day we went into town and ran into her. Okay, we met her and talked to her. After, she talked, but she cried. She talked and cried and we asked, 'What's going on?' She said, 'You all used something on me.' We said, 'Yes, we did it because of your behaviour. If you didn't agree last time, you should have just said so. There's no need for you to swear, because you know what kind of a place we come from.' So after, she apologised, and we said 'sorry' to her back. Okay, now we are reconciled.

So, mostly we use it for women, and also we use it to steal. 
Given the persuasive and pervasive circulation of such narratives, it is no surprise that the above-mentioned report on violence against women found statistical evidence for widespread fear of sorcery amongst ni-Vanuatu women. ${ }^{45}$ Indeed, anecdotal evidence suggests that women routinely switch their phones off at night to avoid their potential use as a conduit for nakaemas. Young women especially are encouraged to remain in the company of close female relatives and not to stray to unfamiliar places or at unfamiliar times. ${ }^{46}$ Even so, as David's narrative demonstrates, the power of nakaemas is such that it can be used to secretly infiltrate even the most familiar of domestic spaces.

Unlike the use of sorcery in chiefly justice, such punitive acts by young men are not socially sanctioned or positively valued. Indeed, at a later point in the interview David explained how he had been counselled and prayed over by members of the Melanesian Brotherhood (see above) on account of his nefarious nakaemas activities, especially following a public revelation of his activities from one of the other men involved in the events described above. As David explained, after exorcising him of the evil demons they believed were causing him to undertake such activities, the Melanesian Brothers had allowed him to continue using his magical powers, so long as he only used them to do good.

As well as demonstrating the entanglement of nakaemas with Christian understandings and expressions of sacred power, ${ }^{47}$ be it in the form of nakaemas or in Christian 'cursing', this also suggests something of the juridical role that is played by Christianity in contemporary Vanuatu. Indeed, if the legal environment of Vanuatu is to be described as 'plural' rather than simply dual as is often the case, such pluralism clearly needs to include a wide range of Christian and other responses, including the once legitimate and still quasi-juridical sphere of sorcery. While sorcery-related conflicts and cases often fall under the purview of kastom law, they are more often handled by Christian means. Church leaders often intervene in sorcery-related cases through a mixture of

\footnotetext{
45 Vanuatu Women's Centre/Vanuatu National Statistics Office, Vanuatu National Survey on Women's Lives and Family Relationships.

46 On the differential value of male and female mobility, and the sexualisation of the latter, see Margaret Jolly, 1999, 'Another time, another place', Oceania 69(4): 282-99.

47 Taylor, 'The troubled histories of a stranger god'; Taylor, 'Two baskets worn at once'; Taylor, 'Sorcery and the moral economy of agency: An ethnographic approach'.
} 
spiritual intervention (including by performing divinations, exorcisms and 'clearances' of malignant spiritual forces, counselling, and dispute management) that includes processes of restorative justice. It also suggests that sorcery is not simply a component of kastom or even of strictly indigenous cosmology and practice, as is often supposed. Rather its contemporary transmutations are intimately linked both to the largely male hierarchies of Christianity ${ }^{48}$ and (as we soon explain) to introduced, hegemonic Western legal frameworks. ${ }^{49}$ Indeed, this may come as no surprise in consideration of the ambivalent unbinding of sorcery from localised social and juridical structures, including male graded hierarchies, but also the crossing over of those hierarchies into broader Christian ones. ${ }^{50}$

The mechanisms of both state and kastom law and governance are heavily monopolised by men in Vanuatu, ${ }^{51}$ as are the hierarchies of Christianity and the magical powers of nakaemas. Indeed, according to the local perspectives and analyses presented above, while tied in the past to male hierarchies as a mechanism for the maintenance of law and order, the nakaemas of today has become dangerously unbound from the law, both state and kastom, and as such has been harnessed for the purposes of more generalised expressions of masculine agency. In this sense, while the use of nakaemas by young and sometimes disempowered men discussed here may be viewed positively as an expression of the 'weapons of the weak', it must also be seen as much more negatively engaged in the enactment of violence against women and in the curbing of women's freedoms more generally.

\section{Conclusions}

Since the 1994 conference attended by Jolly, a great deal of development resources and capacity building have been directed at women's empowerment in Vanuatu, with many positive results. ${ }^{52}$ Despite these efforts, however, pressing questions relating to the

48 See Taylor, 'The troubled histories of a stranger god'; Taylor, 'Two baskets worn at once'.

49 Rio, 'Handling sorcery in a state system of law'.

50 See Taylor, 'The troubled histories of a stranger god'.

51 Margaret Jolly, 2011, 'Flying with two wings? Justice and gender in Vanuatu', The Asia Pacific Journal of Anthropology 12(2): 195-201, p. 196.

52 See Aletta Biersack, 'Human rights work in Papua New Guinea, Fiji and Vanuatu', this volume. 
role of sorcery, sorcery beliefs and fears, and sorcery violenceincluding gender violence-have since that time remained largely unasked. Indeed, despite being clearly implicated in development concerns - especially relating to health and gender violence-sorcery has to this point remained a problematic 'development taboo' within development and health-related discourses and practice in Vanuatu. ${ }^{53}$ While sorcery and religion are classic areas of anthropological interest, issues related to the sacred and especially the negative 'supernatural' are often systematically avoided in development and health industry policy and practice. While possibly bolstered by concerns of cultural relativism, the avoidance of issues regarding belief in the supernatural is continuous with the colonial legacy whereby diverse forms of indigenous agency are only recognised if they conform to biomedical conceptions of causation and reality. ${ }^{54}$ While lip service is occasionally paid to the important role played by Christian and indigenous spiritual beliefs and practices in healthcare, present healthcare-related literature suggests that such refusals to acknowledge or attempt to understand the value of indigenous healing methods, including those aimed at combatting the negative health effects of nakaemas, are still very much the case. Similarly, while international development programs often seek to bolster 'traditional' governance methods and mechanisms, including male chiefly systems, ${ }^{55}$ the pressing issue of how to confront the negative effects of sorcery beliefs and discourse in sorcery-related violence remains unexamined.

This, however, looks set to change. In June 2013, a wide range of scholars, development workers and political and legal representatives met at The Australian National University to discuss the pressing issue of 'Sorcery and witchcraft-related killings in Melanesia: Culture, law and human rights perspectives'. This forum, convened by the State, Society and Governance in Melanesia Project and funded by AusAID, was prompted by a recent and dramatic increase in gruesome

53 Kurt Alan Ver Beek, 2000, 'Spirituality: A development taboo', Development in Practice 10(1): 31-43, p. 31.

54 Alexandra Widmer, 2007, 'Genealogies of biomedicine: Formations of modernity and social change in Vanuatu', PhD thesis, Toronto: York University, p. 30.

55 Volker Boege, 2008, A Promising Liaison: Kastom and State in Bougainville, Brisbane: Australian Centre for Peace and Conflict Studies (ACPACS), University of Queensland; Peter Westoby and Anne M. Brown, 2007, 'Peaceful community development in Vanuatu: A reflection on the Vanuatu kastom governance partnership', Journal of Peacebuilding and Development 3(3): 77-81; Anne Brown, 2007, 'Gender and customary governance in Vanuatu', paper presented at the 10th Pacific Islands Political Studies Association, Port Vila, Vanuatu, 7-8 December. 
gender-related 'witch killings' in Papua New Guinea ${ }^{56}$ that gained media attention internationally and apparently prompted the Papua New Guinea Government not only to revoke its 1971 Sorcery Act but also to reintroduce and broaden death penalty laws for murder, including sorcery-related murder and aggravated rape.${ }^{57}$ While largely focused on Papua New Guinea, as conference conveners Richard Eves and Miranda Forsyth observed, the reason for the instigation of that forum was to address a lack of engagement by development industry practitioners with broader legal and human rights concerns relating to sorcery across the region as a whole. More specifically, and as signalled in a wide-ranging opening address by Forsyth, many of the discussions and debates raised in that forum concerned legal responses to sorcery and sorcery-related violence. This included debates about the role of the law in dealing with practices for which there is an unreliable evidence base. Questions were also raised as to whether sorcery legislation might negatively affect sorcery-related beliefs and practices at a local level, for instance by adversely promoting belief in sorcery or by driving the activities of sorcerers underground. Alongside these discussions ran a stream of detailed descriptive accounts suggesting that fear of sorcery and sorcery-related violence is endemic across the region.

Leaving aside difficult and perhaps unanswerable questions concerning the effectiveness or appropriateness of legal mechanisms in reducing sorcery-related violence, these accounts strongly reinforced the observations concerning sorcery and human rights suggested almost 20 years earlier by women in Vanuatu, as reported by Jolly: that sorcery-related fears and violence are human rights concerns; that, looked at from the local perspective, sorcery itself does constitute a form of violence; ${ }^{58}$ and that sorcery beliefs and sorcery-related violence are invariably if not always structured by locally specific social hierarchies and relations of gender. ${ }^{59}$

56 See Aletta Biersack and Martha Macintyre, 'Introduction: Gender violence and human rights in the western Pacific', this volume; and Biersack, 'Human rights work in Papua New Guinea, Fiji and Vanuatu', this volume; Gibbs, 'Engendered violence and witch-killing in Simbu'. 57 'Amnesty International, 2013, 'Papua New Guinea repeals Sorcery Act while moving closer to executions', News bulletin, 28 May.

58 Jolly, 'Woman Ikat Raet Long Human Raet O No?'

59 Gibbs, 'Engendered violence and witch-killing in Simbu'. 
While acknowledging that the present chapter is based on just a handful of interviews and that further research is required in this area, through engaging a gender-focused analysis with respect to sorceryrelated narratives in Vanuatu, it becomes apparent that sorcery beliefs in this context are structured in such a way that both challenge and uphold hegemonic relations of power. In particular, and in contrast to Papua New Guinea, sorcery in this context is typically-although indeed not exclusively ${ }^{60}$ - understood to be controlled by men, and to be used in such a way as to produce and reproduce hierarchical relations between men and, crucially in the contemporary context, between men and women. This can be clearly seen in what is perhaps the most high-profile sorcery legal case for Vanuatu, the so-called 'Malsoklei case', ${ }^{61}$ as summarised by Forsyth. ${ }^{62}$

A young and possibly mentally unbalanced adolescent wanted to join a group of men who were reputed to engage in sorcery. He was told that they would accept him if he named someone for them to sacrifice and so he named his sister, Roslyn, during an initiation ceremony. Arrangements were made and she was brought to a clearing at night where she was raped by all the men and then one of them killed her and removed her intestines by using a pandanus leaf pushed up her anus. The leader of the group then cut a piece of her liver or heart and gave it to the brother to eat. Another member of the group then had a leaf waved over him and magical words were said to make him resemble Roslyn and he was then sent home in Roslyn's place. A few days later the leader of the group came to her home and asked 'Roslyn' to go to the local nightclub with him and at the nightclub they started to dance. Then suddenly 'Roslyn' fell down and the body was replaced by that of the real Roslyn, who was taken to the local hospital where she was pronounced to be dead, but no autopsy was carried out. In April 1996 the brother went to the police and talked to them about the death of his sister and events which had occurred in the days prior to her death. Four years later, each of the defendants was committed by the Senior Magistrates' Court at Lakatoro to the Supreme Court in 2000. The reason provided for this long delay was that the police did not investigate the matter immediately but waited for five years because they wanted time to let the issue cool down.

60 For example, Forsyth, 'Sorcery and the criminal law in Vanuatu'.

61 Malsoklei v Public Prosecutor [2002] VUCA 28.25.

62 Forsyth, 'Sorcery and the criminal law in Vanuatu', pp. 13-14. 
In this instance it is notable that the violent rape and murder of a young woman occurs as an expression of male power, in particular as an act performed in the production of competitive hierarchical relations between men. Further, while distributing what Connell has termed the 'patriarchal dividend' through masculine acts of physical violence and nakaemas, ${ }^{63}$ here the ambivalent power of sorcery is such that it overpowers the effectiveness of the rule of law. Whether through fear of themselves becoming targets of such malicious nakaemas, both the police and the court appear unable to respond to the crimes committed. Finally, the issue of Rosalyn's brutal murder not only remains unresolved but is subsumed by ambivalent questions about legal process concerning nakaemas itself.

As Eves argues with regard to local knowledge surrounding HIV/ AIDS in Papua New Guinea, if we are to understand the broader context of gender violence, we must seriously and respectfully take account of the local contexts of belief and discourse that structure such behaviour, including how they have changed and continue to change with modernity. ${ }^{64}$ Here we have argued that contemporary sorcery beliefs and associated narratives often represent ambivalent performative expressions of male agency. Such narrative expressions have been demonstrated to be dynamically engaged within multiple spheres of hegemony, first in subverting the effects of state power and its legal mechanisms in particular, and second by reinscribing unequal relations between men and women. This is particularly seen in that, while both men and women are potential victims of health- or fortune-related sorcery attacks, women also live in fear of sex-related sorcery attacks, which often appear as expressions of punitive gender violence. Indeed, in this respect examination of sorcery-related narratives shows nakaemas to represent a largely negative force in society. In the hands of young men, for example, it may be used to subvert the authority of chiefly and state justice. At the same time it works to uphold patriarchy and the generalised subjugation and surveillance of women, including through naturalising sexual violence as a form of social justice.

63 Connell, Masculinities.

64 Richard Eves, 2012, 'Resisting global AIDS knowledges: Born-again Christian narratives of the epidemic from Papua New Guinea', Medical Anthropology 31: 61-76. 


\section{Acknowledgements}

We give thanks first and foremost to the individuals and communities with whom this research was carried out. We are grateful to ARC Laureate Professor Margaret Jolly, and support received from the ARC Laureate project 'Engendering Persons, Transforming Things: Christianities, Commodities and Individualism in Oceania' (FL100100196). This chapter was completed as a part of Dr John Taylor's ARC Discovery Project 'Sorcery and Human Security in Vanuatu' (DP140104244).

\section{References}

Allen, Michael R. 1967. Male Cults and Secret Initiations in Melanesia. Melbourne: Melbourne University Press.

Allen, Michael (ed.). 1981. Vanuatu: Politics, Economics, and Ritual in Island Melanesia. Sydney: Academic Press.

Amnesty International. 2013. 'Papua New Guinea repeals Sorcery Act while moving closer to executions'. News bulletin, 28 May. Online: www.amnesty.org/en/latest/news/2013/05/papua-newguinea-repeals-sorcery-act-while-moving-closer-executions/ (accessed 16 November 2016).

Arendt, Hannah. 1998 [1958]. The Human Condition. Chicago: University of Chicago Press.

Blackwood, Peter. 1981. 'Rank, exchange and leadership in four Vanuatu societies'. In Vanuatu: Politics, Economics and Ritual in Island Melanesia, ed. Michael R. Allen, pp. 35-84. Sydney: Academic Press.

Boege, Volker. 2008. A Promising Liaison: Kastom and State in Bougainville. Brisbane: Australian Centre for Peace and Conflict Studies (ACPACS), University of Queensland.

Bowman, Chakriya, Jozefina Cotura, Amanda Ellis and Clare Manuel. 2009. Women in Vanuatu: Analyzing Challenges to Economic Participation. Washington DC: The World Bank. 
Brown, Anne. 2007. 'Gender and customary governance in Vanuatu'. Paper presented at the 10th Pacific Islands Political Studies Association, Port Vila, Vanuatu, 7-8 December.

Butt, Leslie and Richard Eves (eds). 2008. Making Sense of AIDS: Culture, Sexuality, and Power in Melanesia. Honolulu: University of Hawai'i Press.

Conference on Sorcery and Witchcraft-Related Killings in Melanesia, 5-7 June 2013. Canberra: The Australian National University.

Connell, R.W. 1995. Masculinities. Berkeley: University of California Press.

Crowley, Terry. 1995. A New Bislama Dictionary. Suva, Fiji: Institute of Pacific Studies.

Cummings, Maggie. 2008. 'The trouble with trousers: Gossip, kastom, and sexual culture in Vanuatu'. In Making Sense of AIDS: Culture, Sexuality, and Power in Melanesia, ed. Leslie Butt and Richard Eves, pp. 133-49, Honolulu: University of Hawai'i Press.

Curtis, Tim. 1999. 'Tom's Tambu house: Spacing, status and sacredness in South Malakula, Vanuatu'. Oceania 70(1): 56-71.

Dancause, Kelsey Needham et al. 2013. 'Behavioral risk factors for obesity during health transition in Vanuatu, South Pacific'. Obesity 21(1): E98-E104.

Eriksen, Annelin. 2012. Gender, Christianity and Change in Vanuatu: An Analysis of Social Movements in North Ambrym. Aldershot and Burlington VT: Ashgate Publishing.

Eves, Richard. 2000. 'Sorcery's the curse: Modernity, envy and the flow of sociality in a Melanesian society'. Journal of the Royal Anthropological Institute 6(3): 453-68.

_ 2012. ‘Resisting global AIDS knowledges: Born-again Christian narratives of the epidemic from Papua New Guinea'. Medical Anthropology 31: 61-76. 
Forsyth, Miranda. 2006. 'Sorcery and the criminal law in Vanuatu'. Lawasia Journal 1: 1-27. Online: heinonline. org/HOL/LandingPage?handle=hein.journals/lawasiaj 7 \&div $=5 \& i d=\&$ page $=($ accessed 19 November 2014 $)$.

Forsyth, Miranda and Richard Eves. 2015. Talking it Through: Responses to Sorcery and Witchcraft Beliefs and Practices in Melanesia. Canberra: ANU Press.

Gibbs, Philip. 2012. 'Engendered violence and witch-killing in Simbu'. In Engendering Violence in Papua New Guinea, ed. Margaret Jolly, Christine Stewart and Carolyn Brewer, pp. 107-35. Canberra: ANU E Press. Online: press.anu.edu.au/publications/engenderingviolence-papua-new-guinea (accessed 17 November 2014).

Herriman, Nicholas. 2006. 'Fear and uncertainty: Local perceptions of the sorcerer and the state in an Indonesian witch-hunt'. Asian Journal of Social Sciences 34(3): 360-87.

Jolly, Margaret. 1994. 'Hierarchy and encompassment: Rank, gender and place in Vanuatu and Fiji'. History and Anthropology 7(1-4): 133-67.

1996. 'Woman Ikat Raet Long Human Raet O No? Women's rights, human rights and domestic violence in Vanuatu'. Feminist Review 52: 169-90.

—. 1999. 'Another time, another place'. Oceania 69(4): 282-99.

- 2011. 'Flying with two wings? Justice and gender in Vanuatu'. The Asia Pacific Journal of Anthropology 12(2): 195-201.

Jolly, Margaret, Christine Stewart and Carolyn Brewer (eds). 2012. Engendering Violence in Papua New Guinea. Canberra: ANU E Press. Online: press.anu.edu.au/publications/engendering-violencepapua-new-guinea (accessed 17 November 2014).

Lindstrom, Lamont. 1990. Knowledge and Power in a South Pacific Society. Washington, DC: Smithsonian Institution Press.

McDonnell, Siobhan. 2015. "The land will eat you": Land and sorcery in North Efate, Vanuatu', in Forsyth, Miranda and Richard Eves, Talking it Through: Responses to Sorcery and Witchcraft Beliefs and Practices in Melanesia. pp. 137-160. Canberra: ANU Press. 
Mitchell, Jean. 2011. "'Operation restore public hope": Youth and the magic of modernity in Vanuatu'. Oceania 81(1): 36-50.

O'Brian, Emma. 2007. 'Vanuatu chiefs ban black magic after riot over woman's death'. Bloomberg, 27 March.

Patterson, Mary. 1974. 'Sorcery and witchcraft in Melanesia'. Oceania 45(2): 132-60.

Rio, Knut and Annelin Eriksen. 2013. 'Missionaries, healing and sorcery in Melanesia: A Scottish evangelist in Ambrym Island, Vanuatu'. History and Anthropology 24(3): 398-418.

Rio, Knut. 2002. 'The sorcerer as an absented third person: Formations of fear and anger in Vanuatu'. Social Analysis 46(3): 129-54.

- 2010. 'Handling sorcery in a state system of law: Magic, violence and kastom in Vanuatu'. Oceania 80(2): 182-97.

Rodman, William L. 1973. 'Men of influence, men of rank: Leadership and the graded society on Aoba, New Hebrides'. PhD thesis, University of Chicago.

Rousseau, Benedicta. 2004. 'The achievement of simultaneity: Kastom in contemporary Vanuatu'. PhD thesis, Cambridge University.

Taylor, John P. 2008. 'The social life of rights: Gender antagonism, modernity and raet in Vanuatu'. The Australian Journal of Anthropology 19(2): 165-78.

- 2010, 'Janus and the siren's call: Kava and the articulation of gender and modernity in Vanuatu'. Journal of the Royal Anthropological Institute 16(2): 279-96.

- 2010. 'The troubled histories of a stranger god: Religious crossing, sacred power, and Anglican colonialism in Vanuatu'. Comparative Studies in Society and History 52(2): 418-46.

- 2015. 'Sorcery and the moral economy of agency: An ethnographic approach'. In Gender and Person in Oceania, ed. Anna-Karina Hermkens, Rachel Morgain and John P. Taylor. Special issue of Oceania 85(1): 38-50. 
2016. 'Two baskets worn at once: Christianity, sorcery and sacred power in Vanuatu'. In Christianity, Conflict, and Renewal in Australia and the Pacific, ed. Fiona Magowan and Carolyn Schwarz, pp. 139-60. Leiden: Brill Publishers (under contract).

Tonkinson, Robert. 1981. 'Sorcery and social change in Southeast Ambrym, Vanuatu'. Social Analysis 8: 77-88.

UNIFEM. 2010. 'Ending violence against women and girls: Evidence, data and knowledge in the Pacific Island Countries. Literature review and annotated bibliography'. Suva: UNIFEM Pacific SubRegional Office. Online: www.unicef.org/pacificislands/evaw.pdf (accessed 6 November 2014).

Vanuatu Women's Centre/Vanuatu National Statistics Office. 2011. Vanuatu National Survey on Women's Lives and Family Relationships. Port Vila: Vanuatu Women's Centre. Online: www. spc.int/nmdi/nmdi_documents/VanuatuWomensCentreSurveyWo mensLives2011.pdf (accessed 16 November 2016).

Ver Beek, Kurt Alan. 2000. 'Spirituality: A development taboo'. Development in Practice 10(1): 31-43.

Westoby, Peter and Anne M. Brown. 2007. 'Peaceful community development in Vanuatu: A reflection on the Vanuatu kastom governance partnership'. Journal of Peacebuilding and Development 3(3): 77-81.

Widmer, Alexandra. 2007. 'Genealogies of biomedicine: Formations of modernity and social change in Vanuatu'. PhD thesis. Toronto: York University. 
This text is taken from Gender Violence \& Human Rights: Seeking Justice in Fiji, Papua New Guinea and Vanuatu, edited by Aletta Biersack, Margaret Jolly and Martha Macintyre, published 2016 by ANU Press, The Australian National University, Canberra, Australia. 